\section{NATIVE STRATEGIES FOR RESOURCE MANAGEMENT}

Om Prasad Gurung

I

This paper describes interrelationships among pasture, animal husbandry, and agriculture in Tara village in Baglung District, with emphasis on rittithiti (local management) system. I hypothesized that native strategies of natural resource management are effective and practical, and this hypothesis has been substantiated with the help of primary data, mostly qualitative, collected from the field by applying ethnographic research methods.

\section{II}

Tara village lies between 6,000 and 3,000 ft., northwest of Baglung Bazaar, capital of Baglung District, in western Nepal. The village is bordered by Argal village panchayat in the east, Pandavakhani in the west, Hila in the south and Barangja and Ruma of Myagdi district in the north. There are altogether 497 households. The total population is 3,152 and the total area of the village panchayat is 3,649 hectares 1 . The Tarakhola stream meanders through the heart of the village and cuts the village exactly in half. Along both sides of the stream there are scattered settlements. The climate is temperate and characterized by cold, frost, snowfall and fog in the winter and heavy rainfall and cool wind in summer.

\section{III}

The ethnic composition of the village consists of Magars, Brahmans, Chhetris, Thakalis, Kamis, Sarkis and Damais. The Magars are said to be the oldest inhabitants in the village and to have established most of the social customs in the village.

The village is considered the richest in natural resources in Baglung District. The forest and pasture, lands and water have been exploited by village people through the ages. The forest has provided the villagers fodder, fuel wood, timber, nettle fiber, and wild green vegetables. The major forest type includes gobresalla (Pinus wallichiana), arkhulo (Quercus fenestrata), banjh (Quercus incana), katus (Catanopsis indica), Chilaune (Schima wallichi), Kharus (Quercus semecarpifolia) and utis (Nepal alder). The village is also rich in wild animals and fowls. Mineral resources also exist in the village. In the past, the villagers were diligent miners of iron and copper, but this is no longer true today. However, quarrying of stone and slate is a very common practice in the village. Except in a few cases, water is not used for irrigation. There is a lack of irrigated land in most parts of the village. The cold water of the stream provides fish and facilitates the growth of wild green vegetables along the banks.

\section{IV}

Agriculture is the main component of the village economy, and it is largely supplemented by animal husbandry. Employment outside the village is rare. Because the village is quite isolated, the villagers were not attuned to the opportunities that soldiering offered and were not recruited. Very few are serving in India and they are mostly labourers. Because of this fact, the village people must depend on agriculture and animal husbandry for subsistence.

Ecologically and climatically Tara is not very suitable for agricultural productivity. Although the average landholding size per houschold is relatively larger ( 2.9 hectares) in Tara than in many hill villages of Nepal, agricultural productivity is barely enough to feed her growing population. Types of arable land includes mainly the sim, char and panch, [third, fourth and fifth class] which are less productive, and require more manure to make them fertile. All the arable lands are pakhobari (dry land). Irrigated land is only 3.6 hectares in the entire panchayat. According to the village people, they are able to grow 6.5 muris of major foodgrains (approximately $400 \mathrm{~kg}$ ) in one hal $(0.0677$ hectare) of cultivated land, if the manure of two to three large ruminants is utilized.

Animals' contributions to the agricultural economy of Nepalese hill villages are remarkable. Animals are regarded as a source of socio-economic status. Besides their manure, draft 
service and dairy products, animals contribute extra income to village people. Every villager understands the economic value of their animals. A village proverb says, tangmuni mitho, puchharmuni pitho, which means "animals like buffalo and cattle have milk under their belly and manure under the tails." In other words, such animals are useful simultaneously in several ways. Because of this fact the village people place much emphasis on animal raising and keep as many animals as they can. The panchayat records of Tara show the total population of different livestock as follows: buffalo 2,587; cattle 1,952; sheep 1,591, and goats 953. The total population of all types of livestock is 7,093 , which comes to 14.25 per household or 2.24 per head in the village panchayat. Magars also raise pigs in small numbers and fowls in large numbers, but these animals are not being considered in the present study since they play a very small role in agricultural productivity.

\section{VI}

Feed supply is the most pervasive constraint on livestock production in many hill villages of Nepal. Because the village people depend heavily on the forest for fodder, most researchers allege the depletion of Nepal's forest resources and consequent soil erosion is due to the encroachment of the over population and overgrazing of uncontrolled number of livestock in forest areas (cf. Pandey: 1969, 1983; Miller: 1984; New Era: 1980; Naston: 1983; Bose and Ojha: 1968). Although the population growth and uncontrolled number of livestock have certainly caused a decline in natural resources and soil erosion has been a major problem in many hill villages of Nepal, the situation in Tara is not that bad. Because the village people have their own ritithiti system of grazing management, this has served as a control mechanism for resource management. This is why the Tara village panchayat has been selected for the present study purpose.

The feed resources for livestock in Tara also primarily come from the forest. The forest has provided the animals both forage and pasturage. Katus, phalant, banjh, kharus and arkhaulo are the main fodder trees in the village. The leaves of gobresalla, chilaune, bilaune and utis are used for animal bedding. The crop residues of rice, wheat and barley, and millet straw and maize stalks are also used as animal fodder during winter seasons. But by and large the animals depend on grazing all the year round.

\section{VII}

As in the mountain regions, Tara village has no open grazing lands or kharkas. There are few marginal lands where animals graze during the winter season. In Tara the grazing lands includ mainly the forest. The animals graze under the shadow of trees. In the village almost all the herders have a rich knowledge of ethnobotany. This suggests the intimate relationship between the peasants and the world of the plants. They know some of the poisonous plants (like angeri, guras and pore, trees of the rhododendron family) harmful to domesticated animais and they have native veterinary medicines. Jiro Kawakita (1964:30) also found a similar situation among the Magars of Sikha-Ghara of Nepal.

In Tara almost all the grazing lands lie at the elevation between 7,000 feet and 9,000 feet. The local people call the grazing land lekh/dhuris. There are more than twelve main grazing lands each having a local name such as Lamu, Thulduri, Fagus, Dhunre, Madam, Malrani, Argathum, Tinchule, Julpe, Thundu, Sangdor and Naibeli. The lekh/dhuris include a board range of area which have been supporting a large number of village livestock for several years; if managed as in the present, they can continue to support future livestock at the same level. Previously all these lekh/dhuris were under the control of village heads (mukhiyas), but now they are under the control of the panchayat.

The lekh/dhuris are located on slopes and sometimes steep cliffs. There is enough drinking water in all lekh/dhuris, and they are all rich in grasses. The geographical formation of these lekh/dhuris is such that animals can enter them from only a few main passes (mukhyaghanti). From these main passes the animals are driven out for grazing. These main passes make it easy to keep the area open and closed for proper management.

\section{VIII}

Each household, except for a few Kamis, Sarkis and Damais, who still depend more on their traditional occupations of 
smithing, cobblering and tailoring than on animal husbandry and cultivating lands, send their animals to graze in the lekh/dhuris. Almost all the animals are herded in the lekh/dhuris. Only the best milking animals are stall-fed, because milking animals need more care. The labour requirements for animals depend on the size and types of the animals. Generally one herder is needed for 8 to 10 buffalo or 15 to 20 cattle. Fewer buffalo can be herded, because buffalo are less adaptive to difficult mountain slopes than cattle, and one always has to go after the buffalo to prevent them from falling down difficult slopes. Moreover, buffalo have a higher productive value than cattle, so more attention should be paid for their care. Because of this, a given number of buffalo need more herders than the same number of cattle.

\section{IX}

The grazing cycles are somewhat different for buffalo and cattle. The buffalo are driven out to lekh/dhuris from the first of Jeth (May/June) and graze their till the last of Bhadra (August/September). The cattle are sent to lekh/dhuris from the first of Ashad (mid-June) and graze there till the last of Asoj (September/October). The sheep and goats graze in nearby lower pastures. They are sent out to pasture each morning and brought back to pens each evening, because predators, like wolves, foxes and leopards, always threaten them. They must be kept under constant watch during the day and closely confined at night. Thus grazing is limited to areas relatively close to night pens.

From Asoj (September/October) to Kartik (October/ November) the buffalo and cattle move to agricultural farms to manure the field for winter crops. From Mangsir (November/ December) to Chait (March/April) the animals are kept in stalls, called goths, where they are provided tree fodder and crop residues. During this period the animals are driven out to nearby pasture lands such as pakho, bhir or private pasture lands such as khabari and fallow lands, and brought back to the goths. In the month of Baisakh (April/May), the animals graze in the agricultural farms to manure the fields for the next summer crops. During this month the animals enjoy barely and wheat straw (loshkhuwani) in the field. By the month of Jeth (May/June), the animals again move to lekh/dhuris for grazing. In this way the animals' grazing cycle is completed.

\section{$\mathbf{X}$}

Resource management strategies play a vital role in the agrarian hill societies of Nepal. There is a symbiotic relationship between agriculture and natural resources. Unless natural resources are properly managed, the agricultural productivity will be less than optimal.

In spite of the great contribution of natural resources to agricultural economies, natural resources are declining annually throughout the hills of Nepal. No doubt great efforts have been made by the government and other agencies for better resource management through technical developments. But the emphasis on technical aspects alone is not enough for proper resource management, and social measures adopted by village communities should also be equally taken into consideration.

The existing condition of natural resources, as already stated, is not that bad in Tara village. For many years, generations of village people have heavily depended on natural resources for their agricultural economy. They are aware that the agricultural economy of the village is directly or indirectly related to the quality and quantity of natural resource availability. They say, jabasamma ban tabasamma dhan ("to the extent that there is forest, there is wealth.") Because of this general awareness, village people have contributed to pasture and forest management by adopting various old established procedures, such as grazing on rotational basis, fencing the major passes of grazing lands, and imposing fines if someone violates the communal rules for grazing. Hence Tara village provides a useful example of local resource management practices.

Although the village panchayat has taken over all responsibilities of village heads (mukhiyas), the mukhivas still play a major role in various communal activities in many hill villages of Nepal. Tara village also is no exception. Legally the forest is under the control of the panchayat, but it does not interfere in pasture/forest management and other communal activities. On the day of Shripanchami (one of the Hindu festivals which falls sometime on the last week of January and sometimes on the first week of February), all the heads from each household 
gather together in one common place, customarily at the house of the village head, and make various decisions with regard to resource use for that year. On the same day the date of fencing the pasture/forest and opening the forest/pasture is fixed. Traditionally the first of Baisakh is fixed for fencing the forest and the first of Jeth is fixed for opening the fences. The people reported that the forest/pasture areas are such that there are few manageable open passes and if these could be fenced, animals could not enter them from anywhere. Labour for fencing is compulsory for each household, and those who do not contribute, whether because of negligence or because of engagement in other activities, must pay fines, which ranged from one rupee to five rupees in the early days (now usually five rupees). The total of such collected fines is generally spent for communal feasts.

After completing the fence they perform a puja (ritual) called bansorakni, sacrificing chicken and lambs to please the forest gods and goddesses which otherwise might cause trouble to animals. The participation in this puja is compulsory for each household. They also perform Gauripuja and Bhimsenpuja, sacrificing chickens to protect livestock from evils in the jungle. After performing pujas the messenger (katuwal of the village) declares the opening of fences. Only then do the people start to move towards the lekh/dhuris with their domesticated herds.

The number of domesticated animals is not restricted, but the grazing seasons are restricted. The number of grazing animals averages from 8 to 10 per household. The lekh/dhuris are not grazed more than three times a year. One lekh is grazed for 10 to 15 days. All the lekh/dhuris are not opened together; opening and closing is done on a rotational basis. This practice has been helpful for pasture/forest management.

All types of livestock are not grazed together in one particular grazing land. The village people are quite familiar with the habit and nature of each type of domesticated animal, so they graze the animals separately. Buffaloes are slow browsers and less adaptive to difficult environments, so they are grazed in slopes and plain areas under the shadow of trees. Cattle are grazed in steeper areas, whereas sheeps and goats graze in nearby pasture/forest areas. These practices seem quite reasonable and useful. First, they help to provide fresh pasturage for all types of animals, and second, grazing separately on rotational basis does not result in erosion and deforestation caused by uninterrupted grazing.

The pasture and forest are also used by the people of other neighbouring village panchayats. But they can graze the animals only in limited numbers, and for that they are levied grazing fees called shafal. The rate of grazing fees was one rupee per head of livestock in early days, but now the rate is five rupees. It is collected by the herders and spent for siddhapuja and sometimes for communal feasts.

Opening and closing the fences is done by herders themselves. They decide when and which lekh/dhuris should be opened first. Besides, the herders burn some of the rough pasture/forest patches in winter in order to remove undesirable and unpalatable shrubs and bushes. This practice allows fresh pasturage to grow for the next grazing season. The herders are usually guided by the village head for all these activities. These old established traditional social measures adopted by village communities still function as a social control mechanism for forest/pasture management in Tara village.

\section{I}

Agriculture is the main stay of the village economy in the hills of Nepal. However, it is based, to a greater extent than is realized by many planers and experts, on the quality and quantity of natural resource availability. Agriculture depends on the use of manure, and production of manure depends on the size and types of domestication of animals. In the same way the size and types of domesticated animals are largely determined by availability of pasture/forest resources for feeding. Therefore more attention should be paid to resource management. Village people should be entrusted with resource management, because they themselves are capable of managing their resources through several social practices, which could be adopted in other hill villages. If their traditional social measures are not taken into account, the technical assistance provided by the government for resource management will be futile. In the same way the policy and programmes introduced by the government for resource management will be merely theoretical. 


\section{REFERENCES}

Bose, S.P., and Y.N. Ojha.

1969 Social and Cultural Factors in Agricultural and Forest Development. Kathmandu.

Miller, Daniel J.

1984 Observations and Recommendations Regarding Existing Department of Livestock Development and Animal Health. RCUP, Kathmandu.

Naston, J

1983 Forests and Their Destruction in the Himalayas of Nepal.

New Era.

1980 Community and Forest Development. Kathmandu

Pandey, K.K.

1982 Fodder Trees and Tree Fodder in Nepal. Jointly published by Swiss Development Corporation and Swiss Federal Institute of Forestry Research, Switzerland.

Pandey, K.K., and D.I. Field.

1969 Pasture, Fodder and Livestock Development. UNDEP (Special Fund), Kathmandu.

\section{NATURAL CAUSES AND PROCESSES OF POVERTY IN MICRO SETTINGS}

Tulsi Ram Pandey

\section{Introduction. Methodology and Organization}

Since the 1950's Nepal has completed six periodic plans and has now begun the seventh plan. During this period Nepal also has undertaken a number of local development programs. Unfortunately, the achievement in both types of programs has been dismal. The periodic plans failed to solve "problems relating to poverty, backwardness, unemployment and low productivity" (NPC, 1981a). In the local level development programms "a majority of people have been deceived in matters of sharing benefits" (Upadhyaya, 1984:137). "Mere mounting catchy slogans and coining of claptrap phrases" have comprised our development experiences (NPC, 1984:10). Forty percent of all households do not have a per capita daily income of even two rupees (NPC, 1983:XIV). Nepal, therefore, is "poor and is becoming poorer" daily (ARTEP, 1974:1).

These conclusions have their basis in macro-level information. Such information, despite providing a national picture of poverty in border terms, is unable to explain the micro variations. In the context to extreme geo-cultural variations, "poverty" in Nepal is a micro phenomenon as well. A solution in such a context is thus possible only through micro planning, which needs micro-level studies. This paper is the product of one such micro-level study carried out in a small Tarai village known as Vishasaya in Nawalparasi district.

Questionnaire survey, interview, and observation were the basic techniques of information collection. The total number of households in the village is 291 . Information related to social characteristics such as ethnicity, family size, educational status of family members, sources of income, sectors of expenditure, other survival strategies, migration status, etc., have been 